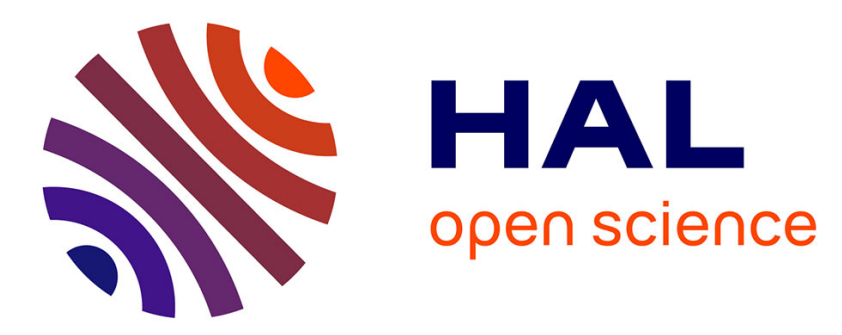

\title{
How high-tech entrepreneurs bricole the evolution of business process management for their activities
}

\author{
Severine Le Loarne, Adnane Maalaoui
}

\section{To cite this version:}

Severine Le Loarne, Adnane Maalaoui. How high-tech entrepreneurs bricole the evolution of business process management for their activities. Business Process Management Journal, 2015, 21 (1), pp.152 - 171. 10.1108/BPMJ-03-2014-0024 . hal-01107743

\section{HAL Id: hal-01107743 \\ https://hal.science/hal-01107743}

Submitted on 21 Jan 2015

HAL is a multi-disciplinary open access archive for the deposit and dissemination of scientific research documents, whether they are published or not. The documents may come from teaching and research institutions in France or abroad, or from public or private research centers.
L'archive ouverte pluridisciplinaire HAL, est destinée au dépôt et à la diffusion de documents scientifiques de niveau recherche, publiés ou non, émanant des établissements d'enseignement et de recherche français ou étrangers, des laboratoires publics ou privés. 


\title{
How high-tech entrepreneurs bricole the evolution of business process management for their activities
}

\author{
Séverine LE LOARNE - LEMAIRE \\ Associate Professor \\ Grenoble Ecole de Management \\ 12, rue Pierre Sémart \\ 38000 GRENOBLE \\ FRANCE
}

$\underline{\text { Severine.le-loarne@grenoble-em.com }}$

Adnan MAALOUI

Associate Professor

ESG Paris - School of Business

25, rue Saint Ambroise

75011 PARIS

FRANCE

maalaoui.adnan@yahoo.fr

\begin{abstract}
:
Purpose: This paper focuses on how entrepreneurs anticipate and change their company's business process management after developing a radical innovation. The paper is based on a critical approach to business process modelling (BPM) that posits that-in spite of all the claims, guides, and tools that companies employ to help them modelise their processes-business processes are developed and improved (or at least changed) by individuals who negotiate, anticipate, and compromise to make these changes occur. Thus, BPM is more a matter of "bricolage" (Levi-Strauss) than an established and defined plan. Based on this position, our paper analyses how a business process model emerges in the early phases of a high tech new venture when the entrepreneur lacks a valid template to form a conceptual representation of the firm's business processes.
\end{abstract}

Design/Methodology/Approach: We adopt a perspective based on the concept of bricolage. By analysing and comparing the discourse of 40 entrepreneurs-20 involved in an activity based on a radical innovation and 20 involved in an activity based on a more incremental concept-we are able to answer the two research questions.

Findings: Entrepreneurs who develop a new activity based on any radical or incremental innovation generally base the BPM of their company and the evolution of this process on existing models. However, BPM generally differs based on the nature of the innovation. Thus, entrepreneurs who develop a new activity based on a radical innovation do not design a single BPM for their company but a portfolio of BPMs. The process by which such entrepreneurs develop such a portfolio is mainly conducted in a step-by-step and iterative approach that utilises "whatever is at hand" (Levi Strauss, 1966). 
Originality/Value: First, this study extends existing methods for and approaches to considering BPM. Second, this research partly answers the call for integration among different theoretical backgrounds and approaches that consider BPM.

Key words: Entrepreneurship, Business Process Modelling, Strategy as Practice, Bricolage, Discourse Analysis

Paper type: research paper 


\title{
How high-tech entrepreneurs bricole the evolution of business process management for their activities
}

\author{
Lessons from a Strategy as Practice Perspective of Entrepreneurship
}

Business process modelling (BPM) is the subject of growing attention from the management sciences. The BPM approach is increasingly used to guide large companies and small and medium-sized enterprises (SMEs) in establishing successful and efficient innovation processes (Le Loarne \& Blanco, 2009) and particularly for developing radical or incremental innovations (Scozzi et al., 2005). This interest appears all the more relevant because studies have shown that many large companies facing a technological breakthrough are unable to react and change their BPM to either adopt the new technology or to employ it to make themselves more competitive (Hill \& Rotharmel, 2003). However, despite the recent claim that the ideal BPM for developing innovations has been identified, studies focusing on the impact of radical innovations on companies' existing BPM remain underdeveloped. The aim of this study is to partly fill this gap by studying how a business model emerges in the early phases of a high tech new venture when the entrepreneur lacks a valid template to form a conceptual representation of the firm's business processes. To answer this question, we ground our approach on the research stream called "Strategy As Practice" (SAP) (Golsorkhi et al., 2010). This approach considers the strategy of a company to be mostly a matter of individuals who may create a vision thanks to tools, roadmaps, and modelling systems but who then interact with other individuals and use the resources they have at hand to create their strategy and act. Based on this research approach, we assume that the high-tech entrepreneur, as CEO and creator of the company, creates the BPM for his emerging activity step by step, using as many resources as he can capture. Therefore, to answer the research question, we will analyse how the high-tech entrepreneur creates and anticipates the BPM of his business activity by using the concept of bricolage as a theoretical grid (Levi Strauss, 1962) and to apply it to the discourses of 20 high-tech entrepreneurs who developed a radical innovation and 20 additional entrepreneurs who created a business activity based on an incremental innovation. Based on this comparison, we propose a description of the process by which high-tech entrepreneurs shape the initial BPM of their activity and make it evolve to develop incremental innovations. More specifically, we highlight the following results of our study: entrepreneurs who develop a new activity based on a radical or incremental innovation primarily base the BPM of their company and the evolution of this process on existing models. However, these business process models generally differ depending on the nature of the innovation. Entrepreneurs who develop a new activity based on a radical innovation do not design a single BPM for their company but typically design a portfolio of BPMs. The process by which they develop such a portfolio generally uses a step-bystep and iterative approach, utilising "whatever is at hand" (Levi Strauss).

\section{Literature Review}

I.1. The "making of" of Business Process Modelling: The missing link 
BPM refers to "an explicit representation (and therefore conceptualisation) of the business processes (of the company): the former aims to improve organisation performance via process reengineering whereas the latter aims to design/redesign the technological solution that best fit the reengineered processes" (Nurcan et al., 2005). Thus, the young discipline associated with this approach (Hammer \& Shampi, 1993; Lee \& Dale, 1998) devoted most of 30 years of research to identifying the different components of BPM (Aguilar-Saven, 2004). These later researchers posit that BPM is risky and time consuming. Therefore, most of the research focuses its effort on creating methods and technics for modelling business processes (Recker et al., 2009 ; ). These methods mainly refer to using the appropriate information system to analyse the data (Giaglis, 2001), to developing visual mapping (Lin et al. 2002), to developing reference models (Lin, Yang \& Pai, 2002 ; Scheer \& Nüttgens, 2000) and evaluate a current Business Process Modeling by companies (Green \& Rosemann, 2000 ; Zur Muehlen M., J. Recher, 2008).

Recent research also insists not only on the methods related to BPM but also on ways to control the modelling such that it is effectively adopted and fits with reality (Kühne et al., 2010; Panayiotou et al., 2013).

However, in spite of the interest in facilitating the modelling process and ensuring that the process matches reality, these attempts mostly focus on methods for developing the visual model. Thus, a research gap remains regarding how CEOs and employees discover the best BPMs for their organisation to adopt, which has resulted in requests for a more cross-disciplinary perspective in BPM research (Aksin et al., 2007; Sidorova \& Isik, 2010). In this vein, our paper aims to partly answer this call by focusing on how a business model emerges in the early phases of a high tech new venture when the entrepreneur lacks a valid template to form a conceptual representation of the firm's business processes. Therefore, we propose adopting a more sociological approach to understanding the process through which a business process is modelled, an approach that has been used to explain how information systems are implemented and reused: bricolage (Cibora, 1996).

\section{II.2. Studying how BPM within the high tech sector emerges and evolves}

The literature on BPM primarily focuses on existing activities and how such activities can be modelled and remodelled. Surprisingly, the literature shows little interest in analysing emerging activities. One possible explanation for this lack of interest is that BPM is typically considered when a company expresses the need to modify it, when it must introduce a new information system such as an ERP System (Le Loarne, 2005) or when it wants to align systems and practice (Doebeli et al., 2011). In other words, BPM is considered when the company is already created, and it is time to "map" the process. However, we argue that the entrepreneurship literature implicitly recognises that business process planning already exists as a new high-tech company is created. Therefore, our research aims to partly address this area. The literature mostly agrees that one major issue for the entrepreneur who develops a radically new business or who wants to commercialise a product/service based on a new disruptive technology is the choice of business model (Chesbrough, 2003, 2010; Baden-Fuller, Haefliger, 2010). The business model refers to "a system that solves the problem of identifying who is (or are) the customer(s), engaging with their needs, delivering satisfaction, and monetising the value" (Baden-Fuller, Haefliger, 2010). This system identifies key stakeholders who 
might help produce or deliver value to customers and how the innovator and the selected stakeholders will share the financial benefit of the value created (Le Loarne \& Blanco, 2012).

However, despite the strong interest in the literature, our research does not focus on the business model but focuses instead on BPM. Indeed, BPM refers to a quite different (more operational, at the least) activity because BPM refers to "an explicit representation (and therefore conceptualisation) of the business processes (of the company), the former aims to improve organisation performance via process reengineering whereas the latter aims to design/redesign the technological solution that best fit the reengineered processes" (Nurcan et al., 2005). The natural link between both concepts has been investigated, research questions have been identified (Osterwalder et al., 2005) and some recent research has concluded the following: "Business models and process models (...) address similar problems on different levels of business (...); A business model is positioned between business strategy and business processes" (Bask et al., 2010). In this paper, although we agree with this conclusion and recognise the strong connection between the business model and BPM, we consider that the analysis of Business Model is not enough for managers: they "just" formalize the value proposition of their business and the generic avenues for producing and delivering that value but cannot, on a practical level really identify where the value can be lost or gained (see for instance Davenport et al. 2004). Therefore, here, we will focus only on how the high-tech entrepreneur shapes the BPM of his activity-and not on how he shapes the business model of his new activity-based on a disruptive technology.

\section{II.3. Bricolage as Theoretical Framework}

\section{Bricolage within the entrepreneurial process}

Bricolage refers to "the process of theoretical tinkering by which individuals and cultures use objects around them to assimilate ideas" (Papert, 1993). This term, which has typically been used as a metaphor (Levis-Strauss, 1966; Abertnathy \& Clark, 1985; Clegg, 1990; Bayon et al. 1996; Orlikowski, 2000) and has recently been elaborated as a concept (Garud \& Karnøe, 2003; Duymedjian \& Rüling, 2010), was developed by Levi Strauss while studying primitive societies constructing their religions. The ethnographer noticed that these people take what they have at hand-an animal, a tree, a natural setting-and recombine these objects, places or persons, which changes their initial purpose and sense and results in the creation of a religion that includes these objects now imbued with a new sense and purpose (Levi-Strauss, 1966). Since that time, this concept has been reused and applied to managerial situations (see Le Loarne, 2006, for a short review) to explain contexts involving high-tech entrepreneurship and knowledge management.

More precisely, Garud and Karnoe (2003) state that high-tech entrepreneurship is not simply a matter of opportunity recognition, as is generally set forth in the literature. Moreover, entrepreneurs interact with many stakeholders-such as users, developers, etc.-as they propose, prototype and improve technology, transforming it into a tangible offer. Using the example of US and Danish companies in the wind energy industry, Garud and Karnoe (2003) show that high-tech entrepreneurship is a matter of bricolage in the sense that entrepreneurs learn by doing and by interacting with their stakeholders 
while improving their technology and progressively defining business opportunities. Baker and Nelson (2005) extend further to analyse the growth of emerging companies that have, by definition, poor access to resources. These authors show that entrepreneurs mainly use what they have at hand to make their businesses run and thus criticise what they call the "objectivist view". In this vein, we posit that entrepreneurs model the business process of their high-tech activities through the development of a bricolage process. However, if we admit that the high-tech entrepreneur bricoles, we still must qualify how.

\section{How high-tech entrepreneurs bricole the business process of their activity}

The recent literature on bricolage proposes certain key guidelines that can serve as a theoretical grid in an analysis of high-tech entrepreneurs modelling their business process and driving its evolution.

Duymedjian and Ruling (2010) contrast the bricoleur and the "ingénieur" on different levels, including the metaphysical, epistemological and practical. The level of practice and the categories they use to characterise practice provide an initial guide. Therefore, these authors consider that bricolage differs from an engineered approach on different levels, as summarised in the following table:

Table 1 - Categories for analysing the practice of the bricoleur and those of the ingénieur

\begin{tabular}{|l|l|l|}
\hline \multicolumn{1}{|c|}{$\begin{array}{c}\text { Category for analysing the } \\
\text { practice }\end{array}$} & \multicolumn{1}{|c|}{ Bricoleur } & \multicolumn{1}{c|}{ Ingénieur } \\
\hline Planning through unplanned & $\begin{array}{l}\text { Search for adequate, project- } \\
\text { oriented means }\end{array}$ \\
\hline Expectations in terms of results & Unclear outcomes & Project and design \\
\hline $\begin{array}{l}\text { Process for answering the } \\
\text { purpose }\end{array}$ & Dialogue with elements in stock & Respect prior specifications \\
\hline Type of resources & Diversion of resources & Seamless integrated system \\
\hline Assessment mode & $\begin{array}{l}\text { Assemblage, substitution } \\
\text { "It's not working" }\end{array}$ & $\begin{array}{l}\text { Evaluation through expected } \\
\text { level of performance / equality }\end{array}$ \\
\hline Process for work & $\begin{array}{l}\text { Creation and use cannot be } \\
\text { dissociated }\end{array}$ & Separation of creation and use \\
\hline $\begin{array}{l}\text { Originality and singularity of the } \\
\text { outcome }\end{array}$ & $\begin{array}{l}\text { Outcomes look unlike anything } \\
\text { else }\end{array}$ & Outcomes respond to field norms \\
\hline
\end{tabular}

Adapted from Duymedjian \& Ruling (2010)

In completing the first grid, the authors also argue that the bricoleur hardly ever works alone and has regular exchanges with partners and stakeholders within his organisation. Therefore, depending on the familiarity he has developed with these persons and the organisation he is working within, the authors distinguish between familiar bricolage and convention-based bricolage. They assume that the bricoleur will have to adapt his way of interacting and collecting information. The difference between the two types of process is presented in chart 2 .

Table 2 - Familiar vs. convention-based bricolage

\begin{tabular}{|l|l|l|}
\hline & \multicolumn{1}{|c|}{ Familiar bricolage } & Convention-based bricolage \\
\hline Time frame & Extended period of time & Less co-presence, shorter period \\
\hline
\end{tabular}




\begin{tabular}{|l|l|l|}
\hline & & of time \\
\hline Space & $\begin{array}{l}\text { Co-presence, defined common } \\
\text { space dedicated to the bricoleurs }\end{array}$ & $\begin{array}{l}\text { More extended, non-exclusive } \\
\text { space }\end{array}$ \\
\hline Repertoire & Shared or mutually accessible & $\begin{array}{l}\text { Separate repertoires, access } \\
\text { regulated by conventions }\end{array}$ \\
\hline Relationship & Closeness, resonance, trust & $\begin{array}{l}\text { Negotiated, some conventions } \\
\text { (which become part of a shared } \\
\text { stock) }\end{array}$ \\
\hline $\begin{array}{l}\text { Conventions } \\
\text { Investments of form }\end{array}$ & $\begin{array}{l}\text { Informal-locally negotiated } \\
\text { Low-medium }\end{array}$ \\
\hline
\end{tabular}

Source: Duymedjian \& Ruling (2010), Organisation Studies, p. 144

The categories proposed in chart 1 and the difference between the familiar bricolage and the convention-based bricolage provide us with an interesting grid for analysing how high-tech entrepreneurs frame the BPM of their activity and drive its evolution.

Based on this framework and the previous work that has been carried out on the concept of bricolage applied to entrepreneurial situations, we can speculate that entrepreneurs, who are starting a new business with hardly no real resources, should better explore what they have at hand and adopt a "Familiar Bricolage" approach. However, since high tech entrepreneurs have to deal with more stakeholders than low tech entrepreneurs, we could state that they have to combine with the interest of these other stakeholders and align their business process to the existing business process by some of their stakeholders, for instance their customers or suppliers. Therefore, we can raise the two following propositions:

P1: Any entrepreneur is starting is business by modelling it thanks to a family based bricolage approach

P2: High-Tech entrepreneurs is rapidly modelling the business process of his / her activity by adopting a convention based bricolage approach

\section{Research Design}

\section{II.1. Epistemological positioning}

The literature on bricolage is mostly focused on defining the concept, and its application to the context of the entrepreneur is rather novel. Therefore, in this research, we did not adopt a hypothetico-deductivist approach (in which we would have derived our research design from hypotheses emerging out of the literature review) and we did not adopt a grounded-theory approach. To the contrary, we adopted an abudctive research approach (Dubois \& Gade, 2002). In this vein, we use theory as a grid for analysing the collected data, but the analysed data help us propose a series of research propositions that address the question of how high-tech entrepreneurs employ BPM to frame and drive their business activities.

\section{II.2. Sample and process for data collection}


Our research question is "How do high-tech entrepreneurs frame the BPM of their respective activities and drive their evolution... when the technology is mature enough and the innovation related to it is less radical?"

To capture the information to answer this question, we obtain data from 40 entrepreneurs. All the entrepreneurs belong to a French network of entrepreneurs, Réseau Entreprendre. Among these 40 entrepreneurs, 20 can be called high-tech entrepreneurs because they developed their business based on the development and exploitation of a new and disruptive technology. This sample composition allows us to better detail the specificity of the process as developed and practiced by the high-tech entrepreneur as opposed to other entrepreneurs. Details regarding the sample are presented in table 3 .

Insert Table 3 about here

We conducted in-depth interviews with each of these 40 entrepreneurs that lasted an average of 2.5 hours, although the longer interviews lasted more than 4 hours. During these interviews, we asked the entrepreneurs to tell the story of the company from its early birth and recognition of its first business opportunity up until the summer of 2013 (see exhibit 1 for me detail on the questionnaire). More precisely, we asked many openended questions to better understand how entrepreneurs organise their business while creating the company and how and why their modelling of their business evolved-or did not evolve-over time.

All the interviews were recorded and transcribed.

\section{II.2. Process for data analysis}

The collected data were coded using Nvivo software. We paid particular attention to how the entrepreneurs explain the modelling of their business process while creating their company, how they drove the evolution of their models and why (if they did). Therefore, we first coded the nature of the company as high-tech or low-tech. For this coding, we referred to Kunkel's classification (Kunkel, 2001), referenced in the Handbook of Research on High-Technology Entrepreneurs (Malakh-Pines \& Ozbilgin, 2010). According to this definition, any venture can be qualified as high-tech when it adopts a techno-push process and when the technology is novel. Next, we coded the data based on an activity perspective focused on how entrepreneurs describe and explain their actions from the creation of the company through the present (Tippman \& Mangematin, 2013). Following Feldman and Orlikowski's recommendation (2011), we used the perspective of the entrepreneur's activity. Therefore, the first author of this paper identified in all the interviews whether the company changed its business process. We call the period during which a company works according to a certain business process a "stage". For each stage, the first author gathered the information provided by the entrepreneurs regarding the five characteristics of bricolage: timeframe, space, repertoire, relationship and conventions / investments of form. Then, for each of the 40 cases and each of the stages, both authors separately qualified the process for modelling the business during this stage as bricolage or as an engineering 
process. Of the 40 cases, the authors disagreed on only 4 cases. For these cases, both authors checked their respective coding and reached a final consensus.

Therefore, the authors propose a grid of BPM according to the nature of the activity of the company, as either low-tech or high-tech.

\section{Results}

Based on our coding, we were able to characterise the bricolage process conducted by the different entrepreneurs to model the business process for their activities. We gathered the cases that presented similarities and found that the "high-tech" variable strongly determines the nature of the BPM process. Following the advice of Langley for studying processes (Langley, 1999), we present the results of our data analysis by employing a longitudinal perspective. First, we present our results on BPM in high-tech companies and second in low-tech companies. To summarise, we note that the high-tech entrepreneur creates the BPM for the activity over time through trial and error. Beginning from a family-based bricolage approach, the entrepreneur uses knowledge gained from his first clients to structure the business process of the activity. Conversely, in the low-tech sectors, the entrepreneur immediately begins his business, obtaining the inspiration for defining the business process from what he observes and from the advice he obtains from consultants or other business partners.

II.1. The creation of BPM in high-tech sectors: Family and conventional bricolage alternatives

In high-tech sectors, we cannot say that there is any proper modelling of the business process during the first years of the company. Specifically, the entrepreneur does not make any real attempt to model any part of his business process or, if he does, this model is not done conducted in purpose. However, the absence of modelling does not indicate that the process is not modelled! After the birth of the company, we observe that most successful high-tech companies (i.e., those companies that survive after 10 years and that achieve regular growth) are run by entrepreneurs who make declarations such as the following:

"I knew perfectly well when I created my business that our job was to develop customized solutions and that, after two or three years, I would have to prepare a transition. To make my organisation evolve, it should be able to develop ready-made solutions" (case 24)

Therefore, we identify three steps of bricolage for BPM during the life of a company: first, a period during which family-based bricolage leads the entrepreneur to create his business; second, a period during which a convention-based bricolage leads to the development of the first BPM; and third, a final period during which family-based bricolage leads the entrepreneur to remodel his business. 
During this period of time, the entrepreneur models the activity of his company while focusing on the first product he is trying to develop and commercialise. The process remains approximately the same for all cases and begins well before the creation of the company. This process occurs within the $R \& D$ centre right after the development of a disruptive technology. The entrepreneur is part of the team who participated in its development. He can be the head of the service and head of the project, as in case 22 (see exhibit 1), a PhD student who was part of the development of one aspect of the technology (case 10), a PhD student who identified one application for the technology he was currently working on (case 3) or a scientist who wanted to create a company and had the opportunity to use an available "technology on the shelves" from her research lab (case 6). Whatever the starting point, the first step consists of answering the same question: "What can we do with this technology in terms of business?" Therefore, once he identifies one application for the technology, the entrepreneur spends his first year bricoling with his research colleagues and simultaneously trying to develop a prototype. The process of bricolage for the BPM of the company as imagined by the entrepreneur can be described as follows (see table 4). During this first phase, business modelling consists of developing a prototype and finding the entrepreneurial team to create the business.

Table 4 - Business Process Modelling - Before the creation of the company

\begin{tabular}{|c|c|c|}
\hline $\begin{array}{l}\text { Category for analysing } \\
\text { the practice }\end{array}$ & Description of the practice & Example (extract of quotations) \\
\hline Planning & $\begin{array}{l}\text { No real planning. } \\
\text { Step by step process }\end{array}$ & \\
\hline $\begin{array}{l}\text { Expectations in terms of } \\
\text { results }\end{array}$ & $\begin{array}{l}\text { Unclear outcomes unless one } \\
\text { team member wants to create a } \\
\text { company out of the technology } \\
\text { development and the rest of the } \\
\text { team agrees with this objective. } \\
\text { The BPM of the future company } \\
\text { is not anticipated and no vision is } \\
\text { clearly defined. }\end{array}$ & $\begin{array}{l}\text { "I had no expectation at that time. I had } \\
\text { done } 3 \text { post-docs and the only thing I } \\
\text { knew was that I wanted to become a } \\
\text { boss. I noticed that in my labs, lots of } \\
\text { technologies were promising but no real } \\
\text { application had been developed. So, I } \\
\text { asked if I could create a company, a } \\
\text { business, using just one. The philosophy } \\
\text { of the lab was to valorise these new } \\
\text { technologies as much as they could, so I } \\
\text { just jumped on the idea" (case 6). }\end{array}$ \\
\hline $\begin{array}{l}\text { Process for answering } \\
\text { the purpose }\end{array}$ & $\begin{array}{l}\text { Dialogue with elements in stock: } \\
\text { Interactions with individuals but } \\
\text { also machines. The feedback } \\
\text { helps enter a new stage of } \\
\text { development. }\end{array}$ & \multirow{2}{*}{$\begin{array}{l}\text { "In my PhD research, I had identified } \\
\text { what we might call a business } \\
\text { opportunity. So I tried to test it and to } \\
\text { nourish it with all the persons I could } \\
\text { meet: my PhD advisor, the head of my } \\
\text { Research Department, and even you as } \\
\text { professor in Management in my doctoral } \\
\text { school. I followed all the courses that } \\
\text { were open to me in management" (case } \\
\text { 3). } \\
\text { "At that time, I wanted to develop a } \\
\text { prototype to present. I identified that } \\
\text { jewellers might be potentially interested. } \\
\text { I knew that because recently I had } \\
\text { lunched with friends and among these }\end{array}$} \\
\hline Type of resources & $\begin{array}{l}\text { Diversion of resources: All the } \\
\text { elements come from the research } \\
\text { lab, including machines, } \\
\text { materials for prototyping but } \\
\text { also human resources in the lab } \\
\text { and, moreover, the business } \\
\text { developer of the lab. }\end{array}$ & \\
\hline
\end{tabular}




\begin{tabular}{|c|c|c|}
\hline & & $\begin{array}{l}\text { friends, one guy was jeweller. I told him } \\
\text { about my idea. I proposed co-developing } \\
\text { a prototype in my lab. I used some } \\
\text { products from the lab, developed a } \\
\text { screen with my team after work and then } \\
\text { came to see the jeweller; together, we } \\
\text { spent the weekend trying to create a new } \\
\text { watch in his garage" (case 26). }\end{array}$ \\
\hline Assessment mode & $\begin{array}{l}\text { No real assessment process for } \\
\text { developing the prototype and } \\
\text { composition of the } \\
\text { entrepreneurial team. The model } \\
\text { is created step-by-step; if it does } \\
\text { not work, then the process is } \\
\text { stopped and another option is } \\
\text { explored. }\end{array}$ & $\begin{array}{l}\text { "How did you compose the team and the } \\
\text { business? It is me and not me who } \\
\text { composes the team! (Laugh) I met } \\
\text { somebody at work who claims to be } \\
\text { interested in the idea. Then, we test and } \\
\text { start working together. If it works, we go } \\
\text { forward, if no, well... that's life" (Case 6). }\end{array}$ \\
\hline Work process & $\begin{array}{l}\text { Creation and use cannot be } \\
\text { dissociated. The BPM is created } \\
\text { thorough interaction between } \\
\text { the entrepreneur and team } \\
\text { members. Some team members } \\
\text { engage themselves, bring new } \\
\text { resources to the process and } \\
\text { thus help create the process. }\end{array}$ & $\begin{array}{l}\text { "I know that the head of my lab would be } \\
\text { interested. He first interacted with us, } \\
\text { and, step-by-step, he joined. Then, when } \\
\text { he was involved, he came with new ideas } \\
\text { but also some resources, and not only } \\
\text { financial" (Case 3) }\end{array}$ \\
\hline $\begin{array}{l}\text { Originality and } \\
\text { singularity of the } \\
\text { outcome }\end{array}$ & $\begin{array}{l}\text { Outcomes look unlike anything } \\
\text { else: A prototype that looks } \\
\text { interesting for imagining the } \\
\text { company and visiting some } \\
\text { clients. }\end{array}$ & $\begin{array}{l}\text { "The new watch": a new screen but on an } \\
\text { existing watch" (case 26). }\end{array}$ \\
\hline
\end{tabular}

During this first phase, the process for business modelling relates to bricolage and implies a series of interactions between the entrepreneur and partners; these partners mostly come from the same research lab and the entrepreneur knows them quite well. For that matter, we could qualify the process as family-based bricolage.

Immediately after company creation: Advanced BPM grounded in convention-based bricolage

According to the different stories of entrepreneurship we collected, the second phase during which we can identify a BPM occurs during the early years of the company's existence. The prototype is here, the first entrepreneurial partners are here and the entire team is helping grow the business by developing a type of "under-measure" service for companies.

The "typical" business process characterising the high-tech companies we studied during this phase is the development of customized services or products for specified clients. Within biotech companies (cases 6, 22, 26 and 27, for instance), the typical activity consists of proposing consulting services that are related to the expertise of the new venture; for example, an expertise related to proteins that address the process of male fertility for case 27 or an expertise related to the fission of proteins for case 26 . The clients in cases 26 and 27 are companies from "big pharmaceutical" activities that are asking for specific competencies for extra development. These clients not only provide a source of revenue to the new venture, but they also make requests that help the research team at the new venture develop and improve the prototype that was 
developed during the most recent phase. Therefore, the business of the company is frequently structured into three parts: the first team specialises in business development and sells services to these clients; the second team, an R\&D team, is devoted to producing the service for the clients; and a third team (sometimes these two last teams are merged to create the third team) is devoted to improving the prototype and developing the medicine. Such a BPM is typical in more than biotech new ventures: we identified such a process within almost all the high-tech companies that comprise our sample. Case 8, which relates to sensors on animals that monitor their temperatures and other variables, perfectly illustrates that point: during the first years of the company, most of the revenues came from services sold to innovative farmers. From the interaction between these clients and the new venture, the entrepreneurial teams succeeded in developing new sensors and improving the existing prototypes.

However, how did the entrepreneur succeed in framing this Business Model? We tend to conclude that this process occurred through a convention-based bricolage process during which the entrepreneur and his team built their business model by combining pragmatism and mimicry. The process is detailed in the following table (Table 5).

Table 5 - Business Process Modelling - First year of company existence

\begin{tabular}{|c|c|c|}
\hline $\begin{array}{l}\text { Category for analysing } \\
\text { the practice }\end{array}$ & Description of the practice & Example (extract of quotations) \\
\hline Planning & $\begin{array}{l}\text { Planning aligned to a business } \\
\text { plan in theory, but, in practice, } \\
\text { a step-by-step process }\end{array}$ & \\
\hline $\begin{array}{l}\text { Expectations in terms of } \\
\text { results }\end{array}$ & $\begin{array}{l}\text { Results defined in terms of } \\
\text { revenues for the business plan, } \\
\text { but these results are not } \\
\text { objectives per se. They represent } \\
\text { a "direction" to follow. }\end{array}$ & $\begin{array}{l}\text { "Yes, yes we define a business plan, as for } \\
\text { any company. That's a proof of } \\
\text { professionalism for the banker, for } \\
\text { business partners as well... but... you } \\
\text { never know... it gives objectives, } \\
\text { directions" (Case 6). }\end{array}$ \\
\hline $\begin{array}{l}\text { Process for answering } \\
\text { the purpose }\end{array}$ & $\begin{array}{l}\text { Dialogue with elements in stock: } \\
\text { Interactions with partners who } \\
\text { bring some resources. However, } \\
\text { these resources are not all } \\
\text { planned in advance. Some (most) } \\
\text { appear during the process, i.e., } \\
\text { when an issue occurs. }\end{array}$ & \multirow{2}{*}{$\begin{array}{l}\text { "When I closed on a client, then we } \\
\text { commonly decided the number of units } \\
\text { and the nature of the micro system I had } \\
\text { to deliver. Of course, I did not have the } \\
\text { microsystem. I knew how to do it but I } \\
\text { did not know if it was possible to reach } \\
\text { the technical specifications requested by } \\
\text { the jeweller. So, the client knew that and } \\
\text { we often interacted and tried to find } \\
\text { solutions to specific issues" (case 23). }\end{array}$} \\
\hline Type of resources & $\begin{array}{l}\text { Diversion of resources: Elements } \\
\text { come from the company, from } \\
\text { partners, and even from the } \\
\text { client. }\end{array}$ & \\
\hline Assessment mode & $\begin{array}{l}\text { The assessment mode does not } \\
\text { really exist yet or, at least, is } \\
\text { grounded by the entrepreneur's } \\
\text { capacity to gain new clients and } \\
\text { to satisfy existing clients (who } \\
\text { mostly evaluate the outputs of } \\
\text { the interaction and the } \\
\text { commonly developed solution) }\end{array}$ & \\
\hline Work process & $\begin{array}{l}\text { Creation and use cannot be } \\
\text { dissociated: The client tests the }\end{array}$ & $\begin{array}{l}\text { "I build my business by trial and error. If } \\
\text { one client seems to be interested in a }\end{array}$ \\
\hline
\end{tabular}




\begin{tabular}{|c|c|c|}
\hline & $\begin{array}{l}\text { solution whereas the } \\
\text { entrepreneur develops the } \\
\text { solution. } \\
\text { The business process model is } \\
\text { also built step-by-step: Based on } \\
\text { the first success, the } \\
\text { entrepreneur continues with the } \\
\text { process. If he believes that new } \\
\text { customers cannot be interested, } \\
\text { he changes the process. }\end{array}$ & $\begin{array}{l}\text { pack on the shelves, I start doing it. If the } \\
\text { client wants a customized solution, I do } \\
\text { it. My top priority is to gain enough } \\
\text { revenue to make the business grow" } \\
\text { (Case 26). } \\
\text { "A potential client is to visit us this } \\
\text { afternoon. He came last week but wanted } \\
\text { to get more results, more things done. He } \\
\text { is here now to check if the advanced } \\
\text { solution he paid for is compatible with } \\
\text { his technical systems" (Case } 3 \text { ). }\end{array}$ \\
\hline $\begin{array}{l}\text { Originality } \\
\text { singularity of the } \\
\text { outcome }\end{array}$ & $\begin{array}{l}\text { Outcomes look unlike anything } \\
\text { else and are different from what } \\
\text { had been anticipated with the } \\
\text { creation of the company. } \\
\text { The business process is more or } \\
\text { less as anticipated by the } \\
\text { entrepreneur but strongly } \\
\text { depends on the interactions he } \\
\text { can have with clients for } \\
\text { developing the products }\end{array}$ & $\begin{array}{l}\text { "Finally, the client who is involved in the } \\
\text { process and the development of the first } \\
\text { product shapes the business process and } \\
\text { the business model: For my case, X } \\
\text { strongly influenced our first product and } \\
\text { when it was time to find other clients, we } \\
\text { had this product as basis" (Case 6). }\end{array}$ \\
\hline
\end{tabular}

We observe that the collected quotations relate more to convention-based bricolage than to family-based bricolage: the team in charge of proposing advanced solutions for the product and a specific solution for a client is also interacting frequently with the client's parallel team and is thus using an unfamiliar stock of knowledge from the client.

Following development of the first activity: Standardised BPM developed during familybased bricolage

The third phase of BPM occurs after the third year in the life of the high-tech company; specifically, it occurs when the entrepreneur and his team become aware that they have enough resources and credibility in the market to capitalise on their activities. During this period, the company has collected a series of experiences with clients and, for each experience, it has gained new knowledge regarding technical and commercial issues. The entrepreneur and his team are now strong enough to launch a product that can target their initial clients' entire market segment.

Therefore, the model begins to change: the entrepreneurial team and the production team begin re-conducting the same process while working for another client, saving time and money while gaining knowledge. Without knowing what is occurring, the entrepreneur is beginning to standardise the business process. Therefore, one complete team is organised to answer generic requests from clients. In parallel to that new process, the old system - customized products or service development-can be maintained in some companies (cases 28 and 29, for instance). Table 6 summarises our observations.

Table 6 - Business Process Modelling - After the company has acquired knowledge from different clients 


\begin{tabular}{|c|c|c|}
\hline Planning & $\begin{array}{l}\text { Planning is more aligned to a } \\
\text { business plan }\end{array}$ & $\begin{array}{l}\text { "We are now working with a controller } \\
\text { who is in charge of setting up a business } \\
\text { plan. Based on that, we monitor the } \\
\text { entire production process" (case 10). }\end{array}$ \\
\hline $\begin{array}{l}\text { Expectations in terms of } \\
\text { results }\end{array}$ & $\begin{array}{l}\text { Results defined in terms of } \\
\text { revenues for the business plan }\end{array}$ & $\begin{array}{l}\text { "This year, we faced a decrease in our } \\
\text { business. That is worrying" (Case 18). }\end{array}$ \\
\hline $\begin{array}{l}\text { Process for answering } \\
\text { the purpose }\end{array}$ & $\begin{array}{l}\text { The marketing team is composed } \\
\text { and proposes "ready made" } \\
\text { offers. The production team } \\
\text { adopts routines. }\end{array}$ & \\
\hline Type of resources & $\begin{array}{l}\text { Resources on stock (stock of } \\
\text { knowledge) }\end{array}$ & \\
\hline Assessment mode & $\begin{array}{l}\text { The capacity for each team to } \\
\text { achieve objectives }\end{array}$ & See case 10 for planning \\
\hline Work process & $\begin{array}{l}\text { More progressive dissociation } \\
\text { between use and creation. }\end{array}$ & $\begin{array}{l}\text { "We set up a production line. Workers } \\
\text { produce, then we stock and sell" (Case } \\
\text { 29). }\end{array}$ \\
\hline $\begin{array}{ll}\begin{array}{l}\text { Originality } \\
\text { singularity of } \\
\text { outcome }\end{array} & \end{array}$ & Standardised services & $\begin{array}{l}\text { "Now, we propose products on shelves } \\
\text { but we still maintain what we call a } \\
\text { "crazy" activity that is not profitable at all } \\
\text { for experimenting on new things with } \\
\text { clients, like before" (Case 29). }\end{array}$ \\
\hline
\end{tabular}

The BPM process in the low-tech sector appears to differ substantially from this threestep BPM process in the high-tech sector.

\section{II.2. BPM modelling in the low-tech sector}

The interviews addressing how entrepreneurs in the low-tech sectors define their business model elucidate two different positions depending on the vision the entrepreneur has for his / her business and his / her own future. The first situation refers to the absence of BPM, or for at least one case, a BPM that is developed through family-based bricolage. On the contrary, the second situation refers to a planned BPM that is copied from an ideal and theoretical BPM.

\section{First situation: A BPM developed through family based bricolage}

In $40 \%$ of our cases, we note that the entrepreneur hardly thought about "Business Process Modelling". Case 1 illustrates the situation:

"I wanted to create my own business. I had two post-docs in biotech and I knew hardly anything about how to create a business. So, I trained myself, took training programs in management and entrepreneurship and jumped into the experience. Nothing was really planned. I had the idea, the idea had been tested and revealed to be good. Its implementation did not require much in terms of resources - my idea was to offer my services to scientists and entrepreneurs, helping them to get sales contacts and appointments for selling-or at least presenting-their technologies. I 
had a full series of contacts. All that I needed was a phone and an office... and my brain!!!"

The expression "jumped into the experience" perfectly explains the situation of some of the entrepreneurs from the low-tech sector in our sample: neither the BPM nor the business model is planned. More precisely, the BPM is implicit, taken for granted and is based on a logical train of thought regarding how to exploit the idea: "I need this, and this... so I do it".

In most cases, entrepreneurs confront difficulties and adapt their way of acting, and therefore their BPM, "on the go". The entrepreneur for case 1 explains:

"Then, I realised that alone, I could not do anything except work very hard day and night; I had to hire somebody to make the business grow, at least to make money... You imagine, I was the only one calling one client. That's OK... but for 10 clients, it is not possible... Thus, I hired an assistant to help me with the administrative details".

However, note that in this case, no real other option was explored. For instance, the entrepreneur could have recruited another salesman who was capable of phoning clients and presenting the technologies. In this case, the entrepreneur "found" the assistant in her network and thought that this assistant could help in her business.

Based on this illustration, we consider that one possible BPM in low-tech sectors is developed though family-based bricolage, as summarised in the following table.

Table 7 - Business Process Modelling 1 in low-tech sectors

\begin{tabular}{|l|l|}
\hline \multicolumn{1}{|c|}{ Category for analysing the practice } & \multicolumn{1}{c|}{ Description of the practice } \\
\hline Planning & No plan. Improvise when the problem occurs. \\
\hline Expectations in terms of results & $\begin{array}{l}\text { No real anticipated result. Vague results: The entrepreneur } \\
\text { wants to live on the revenues of the company. }\end{array}$ \\
\hline Process for answering the purpose & $\begin{array}{l}\text { Using the existing network (for recruiting). Exchanging } \\
\text { with familiar people }\end{array}$ \\
\hline Type of resources & $\begin{array}{l}\text { Resources on stock (stock of knowledge acquired during } \\
\text { training and during past experience, stock of contacts, and } \\
\text { "stock" of persons) }\end{array}$ \\
\hline Assessment mode & $\begin{array}{l}\text { The problem is solved: "Need to outsource administrative } \\
\text { staff-one person is recruited and the need is fulfilled" }\end{array}$ \\
\hline Work process & Improvisation \\
\hline Originality and singularity of the outcome & A unique outcome \\
\hline
\end{tabular}

Second situation: A BPM developed through an "engineered" approach

In the remaining cases, we identify a second process for BPM. This process is characterised as follows. First, this BPM is anticipated much before the creation of the business and is based on a comparison with existing BPM in similar activities. Second, once established, this BPM is almost never modified even when there are difficulties in the business. Case 4 can illustrate these results. In this case, the entrepreneur decided to create a business in which there is little incremental innovation: photography. Interviewed regarding the BPM he developed, he answers as follow: "I already created a company and I had acquired enough experience to set up a business model and a BPM for my new business. More precisely, I ground them by making analogies with what already existed and worked on the market. The idea of making money by specialising in taking 
specific pictures-packages in our case-and working for big groups was something that I did notice before creating my company". Notably, when this entrepreneur notices that large companies are also requesting other internet services, he decides to sell the activity and begin a new business: "I did not want to change jobs and that's it. If I had to do it, I would have had to invest more cash and it was not worth doing... So, I stopped the company. Now, I am creating a new venture that is based on an entirely different business".

II.3. A model of the "making of a BPM" based on the concept of bricolage

To summarise our findings based on the theoretical grid of bricolage presented in our literature review, we can draw a model that synthesises and explains how business process models are developed by high-tech and low-tech entrepreneurs (Graph 1).

Graph 1 - Model of the "making of a BPM" that is based on the concept of bricolage

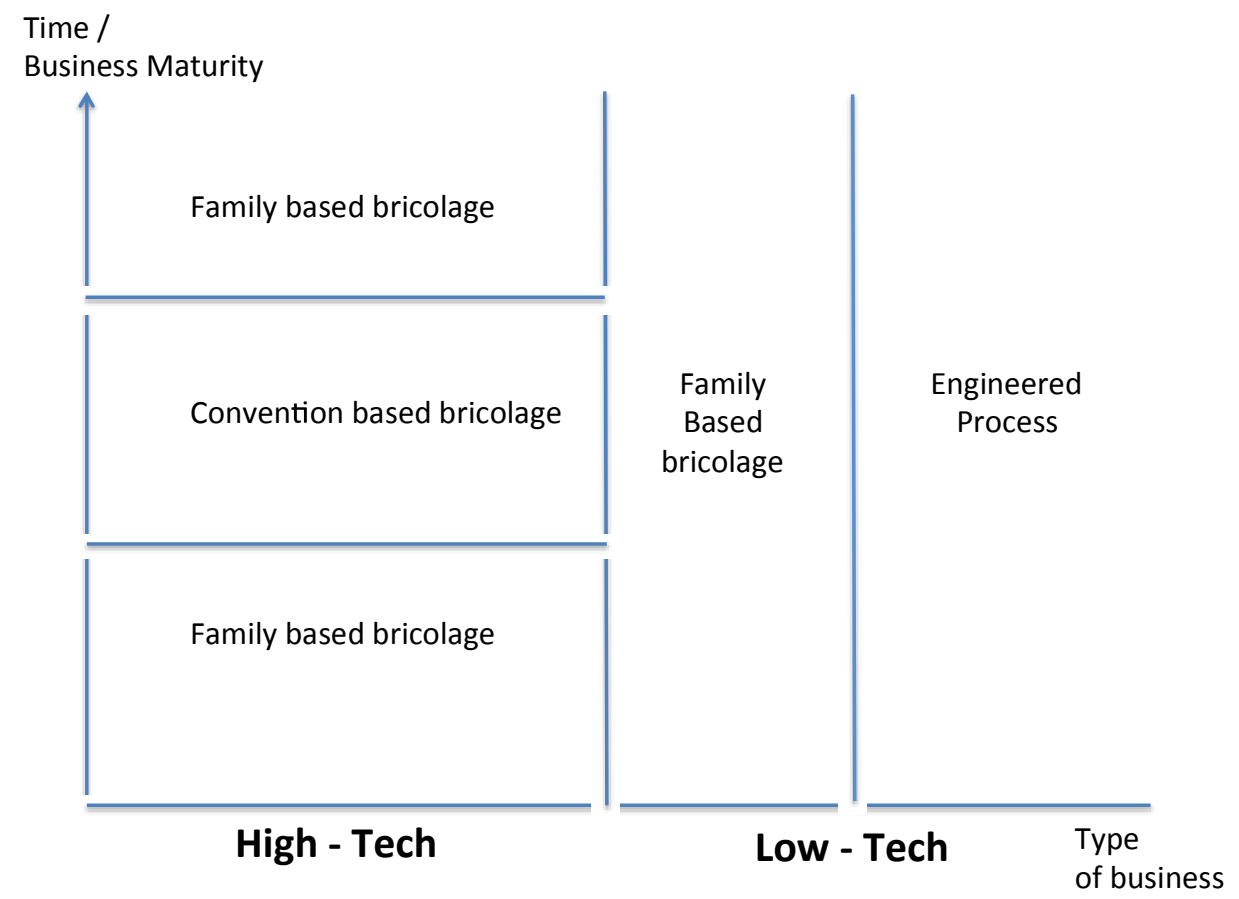

Regarding the first level, our results partly confirm our research propositions. Proposition 1 is supported in a sense that most of the entrepreneurs, either low-tech or high-tech, start their respective business by developing a process that is "bricoled" with what they had at hand:, so adopt a family based bricolage approach. For high tech entrepreneurs, the first orders are opportunity for testing a model of process, model that is improved overtime. Proposition 2 is also supporter but more detailed since we observe that the business process modelling adopted by high tech entrepreneurs remains more complex than expected.

We propose discussing the reasons for these differences in BPM between the low- and high-tech sectors. 
We discover that the business process model evolves over time within any company from the high-tech sector, although this result does not appear to be the case within the low-tech sector. We observe two types of situations within the low-tech sectors: the BPM is either based on an engineering approach, or the BPM hardly exists, which indicates that it consists of applying a pre-existing BPM to the new venture. We did not observe any similar situations in the high-tech sector. One explanation is the nature of the innovation. When a new venture enters an existing market, entrepreneurs can choose between two strategies. The first strategy consists of directly competing with existing competitors and, therefore, adopting their business process. In that case, it appears logical that the entrepreneur adopts a type of engineered approach that is based on established methods that been proven to be effective. The second strategy can be engaged once the entrepreneur considers the market to be mature enough, and it consists of addressing the existing market with a new offer or any new value-added offering, which is frequently associated with a new business model (Mangematin et al., 2003). In this type of situation, the entrepreneur must test the market and find partners to at least validate the offer. Case 30 presents such a situation with a new offer within the event organisation activity and illustrates this point. The aim of the company in case 30 is to find, develop and implement innovative event concepts for clients. Therefore, the business process of the entrepreneur consists of finding one client who is asking for an event under constraints. Most often, the business works with territorial communities that do not have sufficient budget to develop an interesting event to promote their location. The entrepreneur and her team find partners who might be interested in such a location, and step-by-step, the entrepreneur creates and implements the event with all these stakeholders; for instance, a complete day of introduction to rugby for children coming from the French Social Projects in a stadium in the City of Grenoble. The City of Grenoble is having difficulty making the stadium profitable and useful for citizens. A Swiss company seeking to improve its brand image finances the event. The rugby club of Grenoble promotes the sport and children from the projects find an activity for the summer. Other volunteers from private companies offer their time to supervise these children. The task of the entrepreneur is to combine all these ingredients and to create a recipe (Sabatier et al., 2010). This business process has remained stable from the birth of the company. Therefore, based on this illustration, we could argue choosing between an engineered or a bricolage approach relies more on the level of innovation of the offer than on the level of technology involved within the innovation. This assumption is consistent with research in innovation marketing, which posits that the more you innovate, the more you must interact with your environment to adapt the innovation to its market. This interaction is based on a trial and error process and with no guaranteed result (Palmer \& Millier, 2004; Latour, 1996).

The fact that some low-tech and all the new high-tech ventures develop their BPM based on a family-based bricolage approach-as opposed to a convention-based bricolage approach-can be interpreted as indicating that the entrepreneur trusts more people and also trusts the objects and machines he knows when conducting trials and testing the new offer (Gulati, 1995). However, when it is time to grow the business, it is also time to include new clients, and thus to include people and knowledge that are less familiar to the entrepreneurs. Because the development of the new offer is a matter of building a relationship between actors who have never worked together and have no familiarity with the knowledge and resources of their partners, we can easily understand that the relationship is ruled by conventions and the BPM therefore remains grounded in a convention-based bricolage process. 


\section{Conclusion: Discussion, Contribution and Further research}

The contribution of these research results to the BPM theory can be discussed on three main levels.

First, this study shed light on the fact that BPM and Business Models are two complementary and non really dissociable tasks. Most of the low-tech entrepreneurs tend to copy existing business models - i.e. generic ways for creating and delivering a value proposition to consumer - and tend to copy the process and the organization of their company copying the direct competitors. On the contrary, the situation of one lowtech entrepreneurs (whose aim is to develop an original low tech service) and high tech entrepreneurs reveals that BPM is a complicated task since it mostly depends of the choice of the value proposition and, here, in the discourses and collected stories, we notice that the main concern relies in the choice, at least, the identification of the value proposition. In this vein, this research result really claims for a more theoretical reconsideration of both concepts coming from two different theoretical churches: the concept of Business Process Modelling, which emerged within the field of Operation Management, and the concept of Business Model, which streams from the Strategic Management field.

The second point of the discussion deals with the contribution of the concept of bricolage to the understanding of BPM. This research fills the gaps by providing a more interdisciplinary perspective of BPM and, therefore, offering a first attempt to highlight the development of business process modelling in entrepreneurial situations that extends beyond rational methods. This research illustrates the difference in terms of BPM between two situations with high- and low-tech innovations based on an analysis of 40 cases. However, consistent with Langley's findings on qualitative data analysis (Langley, 1999), this research may aspire to propose generic results but is not able to explain on a step-by-step basis the actual creation of BPM. Therefore, as further research, we would recommend more ethnographic studies to understand how entrepreneurs shape their BPM in reality while interacting with clients, in addition to exploring the exact process that leads them to drive the evolution of the BPM as the technology matures and the innovation diffuses more broadly.

The third and last point of discussion relates to our contribution to the BPM Literature and to the diffusion of Operation Management Theories to other audience outside the Operation Management and I.S. Communities. As initially state in the introduction, our aim is to present how entrepreneurs shape the business process model of their company using the concept of bricolage. Our results clearly show that entrepreneurs, generally speaking, do not declare to refer to engineered methods for thinking about this process, especially when they are to develop either any high tech activity or any original or not established yet low tech activity. This can be surprising since, even the education of the entrepreneurs is not part of this research, we can still assume that some of them received an education on Operation Management and Business Process Modelling and, therefore, at least, learnt some basic principles for modelling their business operations. In this vein, these research results question the use of the Business Process Modeling theory and raise two added new research questions: Why are these methods not used? Why do any entrepreneur refers to basic methods? Is it because there is no need of them? That they are not applied to emerging activities? We would rather suggest that we got here a research avenue for future work and suggest a better analysis of the diffusion 
of the BPM Methods among communities such as entrepreneurs and how to educate the audience to BPM Methods. Such a conclusion has also managerial contribution on the interest to BPM theories to get better diffused within the entrepreneurial community and educating high tech entrepreneurs to better think in terms of BPM that could help them to save time in searching the value proposition of their activity. 
Aksin Z., M. Armony, V. Mehrotra (2007), "The Modern Call Center: A Multi-Disciplinary Perspective on Operations Management Research", Production and Operation Management, Vol. 16, №6, p. 665688

Anu H. Bask, Markku Tinnilä, Mervi Rajahonka, (2010) "Matching service strategies, business models and modular business processes", Business Process Management Journal, Vol. 16 Iss: 1, pp.153-180

Aguilar-Save, R.S. (2004), "Business process 20odeling: Reviewand framework", International Journal of Production Economics, 90, p. 129-149

Baden-Fuller C., S. Haefliger (2010), "Business Models and Technological Innovation ", Long Range Planning, Vol. 46 (6), December, p. 419-426.

Ciborra C. (1996), "Introduction: What does Groupware mean for the Organizations hosting it?", in C. Ciborra (Ed.), Groupware and Teamwork: Invisible Aid or Technical Hindrance?, John Wiley \& Sons, Chichester, 1-19

Thomas H. Davenport, Jeanne G. Harris, Susan Cantrell, (2004) "Enterprise systems and ongoing process change", Business Process Management Journal, Vol. 10 Iss: 1, pp.16 - 26

Dubois A., L.E. Gadde (2002), "Systematic combining: An abductive Approach to case research", Journal of Business Research, Vol. 55, 7, p. 553-560

Gaby Doebeli, Ron Fisher, Rod Gapp, Louis Sanzogni, (2011) "Using BPM governance to align systems and practice", Business Process Management Journal, Vol. 17 Iss: 2, pp.184- 202

Green p., M. Rosemann (2000), "Integrated Process Modeling: An Ontological Evaluation", Information Systems, Elsevier, London

Duymedjian R., C. Rülling (2010), "Bricolage in organization and Management Theory", Organization Studies, Vol. 31(2), p. 133-151

Feldman M., W.J. Orlikowski (2011), "Theorizing Pracice and Practicing Theory", Organization Science, $22 / 5$, p. $1240-1253$

Fu-Ren Lin, Meng-Chyn Yang, Yu-Hua Pai, (2002) "A generic structure for business process modeling", Business Process Management Journal, Vol. 8 Iss: 1, pp.19-41

Giaglis G.M. (2001), "A Taxonomy of Business Process Modeling and Information Systems Modeling Techniques", The International Journal of Flexible Manufacturing Systems, 13, p. 209-228

Golsorkhi D., L. Rouleau, D. Seidl (2010), « Cambridge Handbook of Strategy as Practice », Cambridge University Press

Gulati R. (1995), "Does Familiarity breed Trust? The implications of Repeated Ties for Contractual Choice in Alliances", Academy of Management Journal, 38(1), p. 85-112

Hammer G, M. Shampi (1993), « Business Process Reengineering », Harvard Business Press,

Hill, C. W., \& Rothaermel, F. T. (2003). The performance of incumbent firms in the face of radical technological innovation. Academy of Management Review, 28(2), 257-274 
Kühne S., H. Kern, V. Gruhn, R. Laue (2010), "Business Process Modeling with continuous validation", Journal of Software Maintenance and Evolution: Research and Practice, Vol. 22, Issue 6-7, p. 547-566

Kunkel S.W. (2001), "Towards a typology of entrepreneurial activities", Academy of Entrepreneurship Journal, 7(1)

Langley A. (1999), "Strategies for theorizing from process data", Academy of Management Review, 24(4), p. 691-710

Latour B. (1996), Aramis or the love of technology, Harvard Business Press, Cambridge

Le Loarne S. (2005), "Working wth ERP Systems. Is big Brother back?", Computer in Industry, Vol. 56(6), August, p. 523-528

Le Loarne Séverine, Sylvie Blanco $(2009,2012)$, « Management de $l^{\prime}$ Innovation ", $1^{\text {st }}$ and $2^{\text {nd }}$ Edition, Pearson, Paris

Lee R.G., B.G. Dale, (1998) "Business process management: a review and evaluation", Business Process Management Journal, Vol. 4 Iss: 3, pp.214-225

Levi-Strauss C. (1966), The Savage Mind, University of Chicago Press, Chicago

Fu-Ren Lin, Meng-Chyn Yang, Yu-Hua Pai, (2002) "A generic structure for business process modeling", Business Process Management Journal, Vol. 8 Iss: 1, pp.19 - 41

Malakh-Pines A., M. Ozbilgin (2010), "Handbook of Research on High-Technology

Entrepreneurs", Edgar Publishing, Northampton, US, 402p.

Mangematin, V., S. Lemarié, JP Boissin, D. Catherine, F. Corolleur, R. Coronini, M. Trommetter (2003), "Development of SMEs and heterogeneity of trajectories: the case of biotechnology in France", Research Policy, Vol. 32, N4, p. 621-638

Nurcan S., A. Etien, R. Kaabi, I. Zoukar, C. Rolland (2005), "A strategy driven business process 21odeling approach", Business Process Management Journal, Vol. 11(6), p. 628-649

Osterwalder A., Y. Pigneur, C. L. Tucci (2005), “Clarifying Business Models: Origins, Present and Future of the Concept", Communications of the Association for Information Systems, Vol. 15, May

Palmer, R.A., P. Millier (2004), "Segmentation: Identification, Intuition, and Implementation", Industrial Marketing Management, 33(8), p. $779-785$

Panayiotou N.A., I.P. Tatsiopoulos (2013), "Supporting the Design of a Management Accounting System of a Company Operating in the Gas Industry with Business Process Modeling", Advances in Production Management Systems. Competitive Manufacturing for Innovative Products and Services, p. 686-692, Springer, Berlin.

Papert S. (1993), The Children's Machine, Basic Books, New York

Recker, Jan C., Rosemann, Michael, Indulska, Marta, \& Green, Peter (2009) Business process modeling: a comparative analysis. Journal of the Association for Information Systems, 10(4), pp. 333363 
Sabatier V., V. Mangematin, T. Rousselle (2010), "From recipe to dinner: Business Model portfolios in the European Biopharmaceutical industry", Long Range Planning, Vol. 43, Issue 2-3, p. 431-447

Scheer AW, M. Nüttgens (2000), "ARIS architecture and reference models for business process management", in Van der Aalst W et al., (Eds), Business Process Management, p. 376 - 399, Springer Verlag, Berlin

Scozzi Barbara, Claudio Garavelli, Kevin Crowston, (2005) "Methods for modeling and supporting innovation processes in SMEs", European Journal of Innovation Management, Vol. 8 Iss: 1, pp.120 137

Sidorova A., O. Isik, (2010) "Business process research: a cross-disciplinary review", Business Process Management Journal, Vol. 16 Iss: 4, pp.566-597

Tippman E., V. Mangematin, P.S. Scott (2013), "The two faces of Knowledge Search: New Solutions and Capability Development", Organization Studies, Vol. 34, N¹2, p. 1869-1901

Zur Muehlen M., J. Recher (2008), "How much language is enough? Theoretical and practical use of the Business Process Modeling Notation", Advanced Information Systems engineering, p. 465 - 479 
Table 1 - Sample - Summary

\begin{tabular}{|c|c|c|c|c|c|c|}
\hline $\mathbf{N}$ & Activity & $\begin{array}{ll}\text { Type } & \text { of } \\
\text { innovation }\end{array}$ & $\begin{array}{l}\text { Date } \\
\text { of } \\
\text { creation }\end{array}$ & $\begin{array}{c}\text { BPM } 1 \\
\text { (before the } \\
\text { formal } \\
\text { creation of } \\
\text { the } \\
\text { company) }\end{array}$ & $\begin{array}{c}\text { BPM } 2 \\
\text { (right after } \\
\text { the creation } \\
\text { of the } \\
\text { company) }\end{array}$ & $\begin{array}{c}\text { BPM } 2 \\
\text { (when the } \\
\text { company } \\
\text { becomes } \\
\text { mature) }\end{array}$ \\
\hline 1 & $\begin{array}{l}\text { Business } \\
\text { Development } \\
\text { Services for } \\
\text { Biotech Companies }\end{array}$ & $\begin{array}{l}\text { Low tech } \\
\text { innovation }\end{array}$ & 2007 & & $\begin{array}{l}\text { Family based } \\
\text { bricolage }\end{array}$ & $\begin{array}{l}\text { Family based } \\
\text { bricolage }\end{array}$ \\
\hline 2 & Coaching & $\begin{array}{l}\text { Low tech } \\
\text { innovation }\end{array}$ & 2009 & & $\begin{array}{l}\text { Engineered } \\
\text { BPM }\end{array}$ & - \\
\hline 3 & $\begin{array}{l}\text { Rechargeable } \\
\text { batteries }\end{array}$ & High Tech & 2011 & $\begin{array}{l}\text { Family based } \\
\text { bricolage }\end{array}$ & $\begin{array}{l}\text { Convention } \\
\text { based } \\
\text { bricolage }\end{array}$ & $\begin{array}{l}\text { Family based } \\
\text { bricolage }\end{array}$ \\
\hline 4 & Photography & Low Tech & 1990 & & $\begin{array}{l}\text { Engineered } \\
\text { BPM }\end{array}$ & - \\
\hline 5 & Wire installations & Low Tech & 2003 & & $\begin{array}{l}\text { Engineered } \\
\text { BPM }\end{array}$ & - \\
\hline 6 & Biotech - Protein & High Tech & 2003 & $\begin{array}{l}\text { Family based } \\
\text { bricolage }\end{array}$ & $\begin{array}{l}\text { Convention } \\
\text { based } \\
\text { bricolage }\end{array}$ & - \\
\hline 7 & Catering & Low Tech & 2006 & & $\begin{array}{l}\text { Family based } \\
\text { bricolage }\end{array}$ & - \\
\hline 8 & $\begin{array}{l}\text { Software - devices } \\
\text { applications }\end{array}$ & High Tech & 2006 & $\begin{array}{l}\text { Family based } \\
\text { bricolage }\end{array}$ & $\begin{array}{l}\text { Convention } \\
\text { based } \\
\text { bricolage }\end{array}$ & $\begin{array}{l}\text { Family based } \\
\text { bricolage }\end{array}$ \\
\hline 9 & Building & $\begin{array}{l}\text { Low Tech } \\
\text { but use } \\
\text { of a disruptive } \\
\text { service } \\
\text { innovation } \\
\end{array}$ & 2002 & & $\begin{array}{l}\text { Engineered } \\
\text { Approach }\end{array}$ & - \\
\hline 10 & Sensors on animals & High Tech & 2004 & $\begin{array}{l}\text { Family based } \\
\text { bricolage }\end{array}$ & $\begin{array}{l}\text { Convention } \\
\text { based } \\
\text { bricolage }\end{array}$ & - \\
\hline 11 & $\begin{array}{l}\text { Biotech - diagnosis } \\
\text { for heart diseases }\end{array}$ & High Tech & 2000 & $\begin{array}{l}\text { Family based } \\
\text { bricolage }\end{array}$ & $\begin{array}{l}\text { Convention } \\
\text { based } \\
\text { bricolage } \\
\end{array}$ & - \\
\hline 12 & Clothing & Low Tech & 1993 & & $\begin{array}{l}\text { Family based } \\
\text { bricolage }\end{array}$ & $\begin{array}{l}\text { Engineered } \\
\text { Approach }\end{array}$ \\
\hline 13 & Children Nursery & Low Tech & 2007 & & $\begin{array}{l}\text { Engineered } \\
\text { Approach }\end{array}$ & - \\
\hline 14 & $\begin{array}{ll}\text { Bank Credit for } \\
\text { building }\end{array}$ & Low Tech & 2012 & & $\begin{array}{l}\text { Engineered } \\
\text { Approach }\end{array}$ & - \\
\hline 15 & $\begin{array}{l}\text { Tourist } \\
\text { Transportation }\end{array}$ & Low Tech & 2006 & & $\begin{array}{l}\text { Engineered } \\
\text { Approach }\end{array}$ & - \\
\hline 16 & Purchasing Export & Low Tech & 2009 & & $\begin{array}{l}\text { Engineered } \\
\text { Approach }\end{array}$ & - \\
\hline
\end{tabular}




\begin{tabular}{|c|c|c|c|c|c|c|}
\hline 17 & $\begin{array}{l}\text { Firm coaching on } \\
\text { new forms of } \\
\text { organizations }\end{array}$ & Low Tech & 2010 & & $\begin{array}{l}\text { Family based } \\
\text { bricolage }\end{array}$ & - \\
\hline 18 & Satellite services & High Tech & 2003 & $\begin{array}{l}\text { Family based } \\
\text { bricolage }\end{array}$ & $\begin{array}{l}\text { Mimetism } \\
\text { and } \\
\text { Convention }\end{array}$ & - \\
\hline 19 & $\begin{array}{l}\text { Telecommunication } \\
\text { services }\end{array}$ & High Tech & 2002 & $\begin{array}{l}\text { Family based } \\
\text { bricolage }\end{array}$ & $\begin{array}{l}\text { Convention } \\
\text { based } \\
\text { bricolage }\end{array}$ & - \\
\hline 20 & $\begin{array}{l}\text { Outsourced } \\
\text { services dealing } \\
\text { with HRM for } \\
\text { companies }\end{array}$ & Low Tech & 2007 & & $\begin{array}{l}\text { Family based } \\
\text { bricolage }\end{array}$ & $\begin{array}{l}\text { Engineered } \\
\text { Approach }\end{array}$ \\
\hline 21 & $\begin{array}{l}\text { No Tabac Cigarette } \\
\text { Shop }\end{array}$ & Low Tech & 2006 & & $\begin{array}{l}\text { Engineered } \\
\text { Approach }\end{array}$ & - \\
\hline 22 & Biotech 1 & High Tech & 2010 & $\begin{array}{l}\text { Family based } \\
\text { bricolage }\end{array}$ & - & - \\
\hline 23 & Semi-conductors & High Tech & 2006 & $\begin{array}{l}\text { Family based } \\
\text { bricolage }\end{array}$ & $\begin{array}{l}\text { Convention } \\
\text { based } \\
\text { bricolage }\end{array}$ & $\begin{array}{l}\text { Family based } \\
\text { bricolage }\end{array}$ \\
\hline 24 & $\begin{array}{l}\text { Devices based on a } \\
\text { new motion } \\
\text { capture }\end{array}$ & High Tech & 2011 & $\begin{array}{l}\text { Family based } \\
\text { bricolage }\end{array}$ & - & - \\
\hline 25 & IS Modeling & High Tech & 2001 & $\begin{array}{l}\text { Family based } \\
\text { bricolage }\end{array}$ & $\begin{array}{l}\text { Convention } \\
\text { based } \\
\text { bricolage }\end{array}$ & $\begin{array}{l}\text { Family based } \\
\text { bricolage }\end{array}$ \\
\hline 26 & Biotech 2 & High Tech & 1999 & $\begin{array}{l}\text { Family based } \\
\text { bricolage }\end{array}$ & $\begin{array}{c}\text { Convention } \\
\text { based } \\
\text { bricolage }\end{array}$ & $\begin{array}{l}\text { Family based } \\
\text { bricolage }\end{array}$ \\
\hline 27 & Biotech 3 & High Tech & 2003 & $\begin{array}{l}\text { Family based } \\
\text { bricolage }\end{array}$ & $\begin{array}{l}\text { Convention } \\
\text { based } \\
\text { bricolage }\end{array}$ & $\begin{array}{l}\text { Family based } \\
\text { bricolage }\end{array}$ \\
\hline 28 & Micro-electronics & High Tech & 1996 & $\begin{array}{l}\text { Family based } \\
\text { bricolage }\end{array}$ & $\begin{array}{l}\text { Convention } \\
\text { based } \\
\text { bricolage }\end{array}$ & $\begin{array}{l}\text { Family based } \\
\text { bricolage }\end{array}$ \\
\hline 29 & $\begin{array}{l}\text { Lighting systems } \\
\text { through hydrogen } \\
\text { balloons }\end{array}$ & High Tech & 1996 & $\begin{array}{l}\text { Family based } \\
\text { bricolage }\end{array}$ & $\begin{array}{l}\text { Convention } \\
\text { based } \\
\text { bricolage }\end{array}$ & $\begin{array}{l}\text { Family based } \\
\text { bricolage }\end{array}$ \\
\hline 30 & Events & Low Tech & 2006 & & $\begin{array}{l}\text { Family based } \\
\text { bricolage }\end{array}$ & - \\
\hline 31 & Outsourced HRM & Low Tech & 2012 & & $\begin{array}{l}\text { Engineered } \\
\text { Approach }\end{array}$ & - \\
\hline 32 & Coaching & Low Tech & 2008 & & $\begin{array}{l}\text { Engineered } \\
\text { Approach }\end{array}$ & - \\
\hline 33 & Motion Capture & High Tech & 2011 & $\begin{array}{l}\text { Family based } \\
\text { bricolage }\end{array}$ & - & - \\
\hline 34 & Micro-electronics & High Tech & 1983 & $\begin{array}{l}\text { Family based } \\
\text { bricolage }\end{array}$ & $\begin{array}{l}\text { Convention } \\
\text { based } \\
\text { bricolage }\end{array}$ & $\begin{array}{l}\text { Family based } \\
\text { bricolage }\end{array}$ \\
\hline 35 & $\begin{array}{l}\text { Housing } \\
\text { architecture }\end{array}$ & Low Tech & 2008 & & $\begin{array}{l}\text { Engineered } \\
\text { Approach }\end{array}$ & - \\
\hline
\end{tabular}




\begin{tabular}{|c|l|l|l|l|c|c|}
\hline 36 & Events 2 & Low Tech & 2004 & & $\begin{array}{l}\text { Engineered } \\
\text { Approach }\end{array}$ & - \\
\hline 37 & Ski motion & High Tech & 2007 & $\begin{array}{l}\text { Family based } \\
\text { bricolage }\end{array}$ & - & - \\
\hline 38 & Motion Capture 2 & High Tech & 2007 & $\begin{array}{l}\text { Family based } \\
\text { bricolage }\end{array}$ & $\begin{array}{l}\text { Convention } \\
\text { Based } \\
\text { bricolage }\end{array}$ & - \\
\hline 39 & Ski design & High Tech & 2012 & $\begin{array}{l}\text { Convention } \\
\text { Based } \\
\text { bricolage }\end{array}$ & - & - \\
\hline 40 & Sensors & High Tech & 2011 & $\begin{array}{l}\text { Family based } \\
\text { bricolage }\end{array}$ & - & - \\
\hline
\end{tabular}


Exhibit 1 - Data collection, semi-structured Questionnaire

Company:

Name of the Entrepreneur (Majority Shareholder + creator) :

Date of Creation:

Activity:

1) How to you currently describe your business

2) Can you please tell us the story of your company, from the early stages on the opportunity identification till now

3) How would you describe the initial Value Proposition to Customers of your company and describe how your company has been structured (with other partners) to deliver that value. How did you choose this value proposition and the process?

4) Since the creation, how this value proposition evolved and how the structure of the business process modeling evolve (if so). Why and how? 